\title{
EARLY RESULTS OF MICRO-DEFORMATION MEASUREMENTS IN MAGDALENA JAMA (SLOVENIA) BY A VERTICAL STATIC PENDULUM
}

\author{
ZAČETNI REZULTATI MERJENJA MIKRO-DEFORMACIJ \\ V MAGDALENI JAMI (SLOVENIJA) Z NAVPIČNIM \\ STATIČNIM NIHALOM
}

\author{
Pavel KALENDA ${ }^{1}$, Libor NEUMANN ${ }^{2} \&$ Stanka ŠEBELA ${ }^{3}$
}

\begin{abstract}
UDC 550.348:551.435.84(497.4)
Pavel Kalenda, Libor Neumann \& Stanka Šebela: Early results of micro-deformation measurements in Magdalena Jama (Slovenia) by a vertical static pendulum

Vertical static pendulums have been installed in mines or caves in Central Europe since 2007. Two-dimensional optical measurement of the tilt of a rock mass and continuous fully digital on-line evaluation of results makes possible the detection of a small tilt of the surroundings with a resolution of tens of nanoradians or the deformation of the surroundings in the horizontal plane with resolution of hundreds of nanometres. The paper describes the measurement device and the first results of the measurements in Magdalena Jama, which is part of the Postojna Cave System (Slovenia). The correlation of deformation between distant stations shows the existence of stress variations that are not only of local origin (high floods, local seismicity, and aseismic deformations). The stress field has a wider, and not only regional, character with effects that can be observed very far from the origin.

Keywords: vertical static pendulum, stress changes, earthquake precursors, Magdalena Jama, Slovenia.
\end{abstract}

Izvleček

UDK 550.348:551.435.84(497.4)

Pavel Kalenda, Libor Neumann \& Stanka Šebela: Začetni rezultati merjenja mikro-deformacij $v$ Magdaleni jami (Slovenija) z navpičnim statičnim nihalom

Navpična statična nihala so $\mathrm{v}$ rudnikih ali jamah osrednje Evrope nameščena od leta 2007. Dvo-dimenzionalni optični inštrument, ki meri nagib kamninske mase ter digitalno vrednotenje rezultatov $\mathrm{v}$ realnem času omogočajo določanje majhnih nagibov okolice $\mathrm{z}$ natančnostjo desetih nanoradianov ali deformacij okolice $\mathrm{v}$ horizontalni ravnini $\mathrm{z}$ natančnostjo sto nanometrov. Članek opisuje merilni inštrument ter prve rezultate meritev v Magdaleni jami, ki je del Postojnskega jamskega sistema (Slovenija). Primerjava deformacij med oddaljenimi postajami pokaže obstoj napetostnih razlik, ki nimajo samo lokalni izvor (visoke poplave, lokalna seizmičnost, neseizmične deformacije). Napetostno polje ima širši in ne samo regionalni značaj z učinki, ki jih lahko opazujemo na velikih razdaljah od izvora.

Ključne besede: navpično statično nihalo, spremembe napetosti, predhodniki potresov, Magdalena jama, Slovenija.

\section{INTRODUCTION}

The Postojna Cave System is a very suitable place to study the tectonic deformations in Slovenia (Šebela et al. 2010, Gosar et al. 2011). For this purpose Magdalena Jama was chosen as the best location for vertical static pendulum installation in Slovenia. It is part of the Postojna Cave System, which is, with a length of $20,570 \mathrm{~km}$, the second longest cave system in Slovenia. The entrance to Magdalena Jama is in the forest at $562 \mathrm{~m}$ above sea level and the cave is $1,395 \mathrm{~m}$ long and $89 \mathrm{~m}$ deep. The entrance consists of two vertical shafts that are 15 and $35 \mathrm{~m}$ deep, respectively.

\footnotetext{
${ }^{1}$ Institute of Rock Structure and Mechanics, Academy of Sciences of the Czech Republic, V Holešovičkách 41, 18209 Prague, Czech Republic (p.kalenda@volny.cz)

${ }^{2}$ ANECT, a.s., A. Staška 79, Prague, Czech Republic (Libor.Neumann@email.cz)

${ }^{3}$ ZRC SAZU Karst Research Institute, Titov trg 2, 6230 Postojna, Slovenia (sebela@zrc-sazu.si)
}

Received/Prejeto: 7.5.2012 
It is important to measure the stress in rocks continuously using direct or indirect methods (Crampin \& Gao 2009, Shi et al. 2009). The most common methods for indirect measurement of stress at seismogenic depths are these based on measurement of strain or tilt of rocks. From the instrumentation point of view, the tilt-measuring methods were the first to be used (Melchior 1983, Braitenberg et al. 2006, Grillo et al. 2011). In sporadic cases they measured anomalies preceding earthquakes (Biagi et al. 1976, Braitenberg 1999). Strain measurement is widely used in China (Li et al. 2003), where measurements were taken in 358 areas in 2009 (Shi et al. 2009). The relative measurement of movement of the sides of active faults by various dilatometers can show the periods of fault activity, when the Coulomb criterion on the fault is fulfilled (Stemberk et al. 2003, Gosar et al. 2009, Šebela et al. 2010, Gosar et al. 2011, Kalenda et al. 2011b, Košták et al. 2011).

With the on-line registration of the $2 \mathrm{D}$ microdeformations of the vertical static pendulum we aim to show the short-term displacement changes related to local and world-wide seismicity, as well as relationships with karst underground water situations. Comparison of tilt between Magdalena Jama (Slovenia) and Ida gallery (Czech Republic) detected by static vertical pendulums is discussed.

\section{METHODOLOGY}

The installation of vertical static pendulum in Magdalena Jama started in 2009 and it has been in operation since 3 July 2010.

Because the tectonic stress in the rock mass is mostly horizontal (Staš \& Souček 2002), the common deformations will be in vertical directions (Fig. 1). We suggested a quite new apparatus for indirect stress measurement, based on the vertical static pendulum (Neumann 2007, Kalenda et al. 2009, Neumann \& Kalenda 2010).

A vertical static pendulum consists of a concrete mass, which is hung on the rod. The microraster is placed on the mass. A camera, mounted on the microscope and connected with the wall, takes pictures of the raster every 10 seconds. The pictures are sent to the measuring PC, which evaluates the contour diagrams (Marble Project 1996) and transforms them into displacement in two directions, $X$ and $Y$. The raw data are sent to the transmitting PC, which is connected with a data server via GSM modem (Neumann \& Kalenda 2010).

The vertical static pendulum is able to measure the displacement $\boldsymbol{d} \boldsymbol{s}$ in the horizontal plane with a preci- sion of hundreds of nanometers or the tilt of plumb line $\boldsymbol{\alpha}$ with a precision of tens of nanoradians, depending on the length of the pendulum (Fig. 1) (Kalenda et al. 2009).

Such measurement is advantageous as it excludes errors due to friction. Absolute difference between the actual position and any previous one at any time can be calculated. In this way we can find long-term deformation trends in endless time periods, long anomalous deformation paths of weeks and months duration, as well as short-time changes in days.

The vertical static pendulum is highly sensitive to all kind of interference, which is a disadvantage. It will react to traffic, people walking, drought, changes in humidity and temperature. Therefore, the best places for measurement are in underground chambers in caves or old abandoned mines, with no traffic, no wind and only small temperature changes.

The first vertical static pendulum was installed underground in the Czech Republic in 2007 in an abandoned mine gallery in Př́bram (Fig. 2 - P7), where only a)

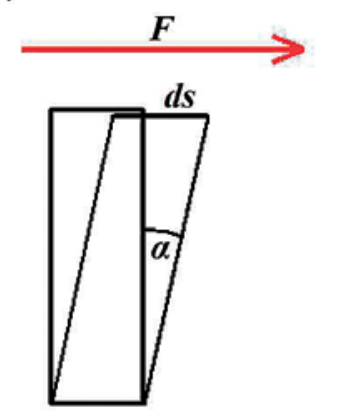

b)

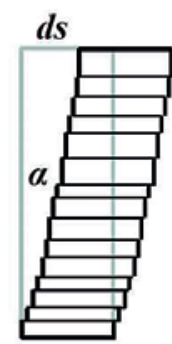

c)

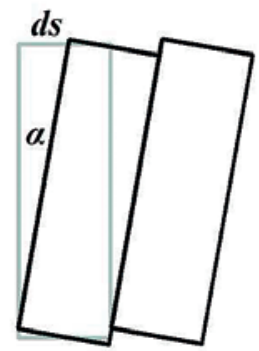

Fig. 1: Most common deformations of rock mass by horizontal force $F-a)$ strain and rotation, b) layering, c) pure rotation. 


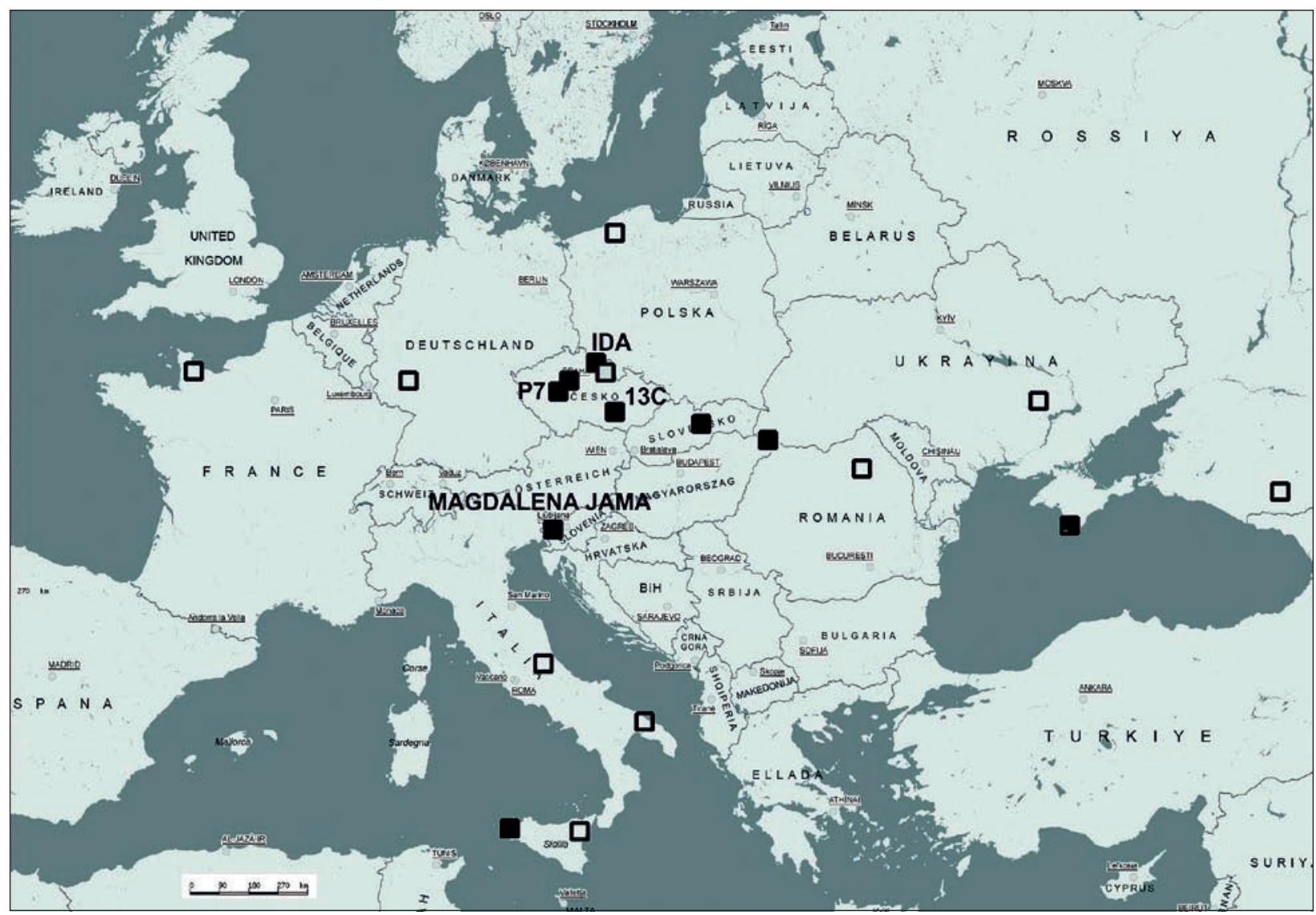

Fig. 2: The vertical static pendulum deployment map; status in January 2012; black squares - pendulums in operation, white squares planed.

highly scientific instrumentation is active (Skalský 1963 , Skalský \& Pícha 1965), and only operators are allowed to enter. A suitable environment is also found in the Moravian karst, in the cave No.13C (Fig. 2), which is closed to the public.

Eleven pendulums were in operation underground in Central Europe in January of 2012 (Fig. 2).

To separate local and regional deformations, we suggested installing the pendulums on two profiles crossing Europe (Fig. 2); N - S profile from Poland to Sicily (Italy) and $\mathrm{E}-\mathrm{W}$ profile from France to the Caucasus. The distance between the pendulums should be $600-1000 \mathrm{~km}$. The first station outside the Czech Republic was installed in 2008 in Slovakia. In 2008 one pendulum was installed in Koševa Jama in SW Slovenia, but it was destroyed during the snowmelt in the spring of 2009, and the project was cancelled. In 2009 two new stations were installed, one pendulum $26.3 \mathrm{~m}$ long in Magdalena Jama, Slovenia (Figs. 3D, 4, 5 and 6), and another in Marsala on Sicily (Italy).

For more than a year they were not in operation due to problems with power supply. These problems (Fig. 7) were solved in Slovenia in June 2010 by installing a new solar panel, and now we are obtaining the first on-line transmitted data.

\section{GEOLOGY OF THE STUDIED AREA}

Slovenia is situated at the border between the Adria microplate and the Eurasia plate and is characterized by complex and neotectonically active geological conditions.
Since the late Miocene to Pliocene, paleomagnetic data had indicated about $30^{\circ}$ counter-clockwise rotation of the Adria microplate (Márton et al. 2003). From Paleogene to recent, the thrust belts along the 


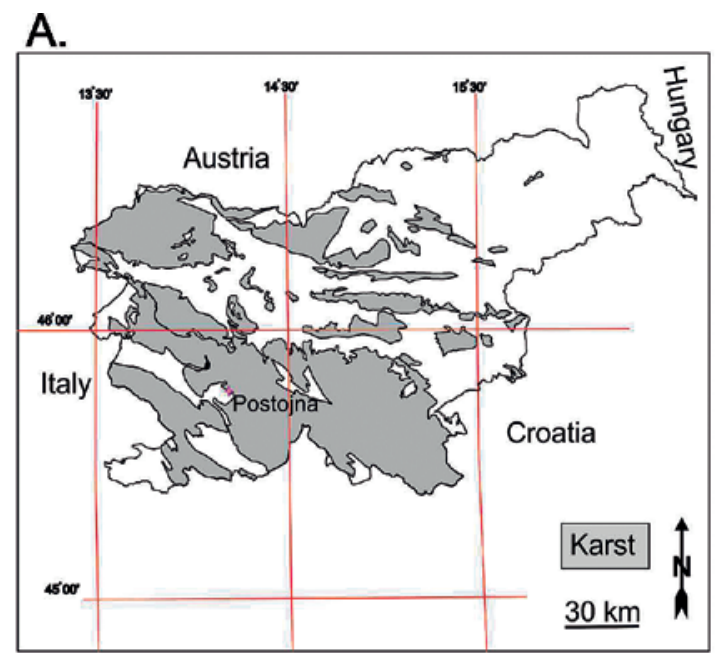

C.

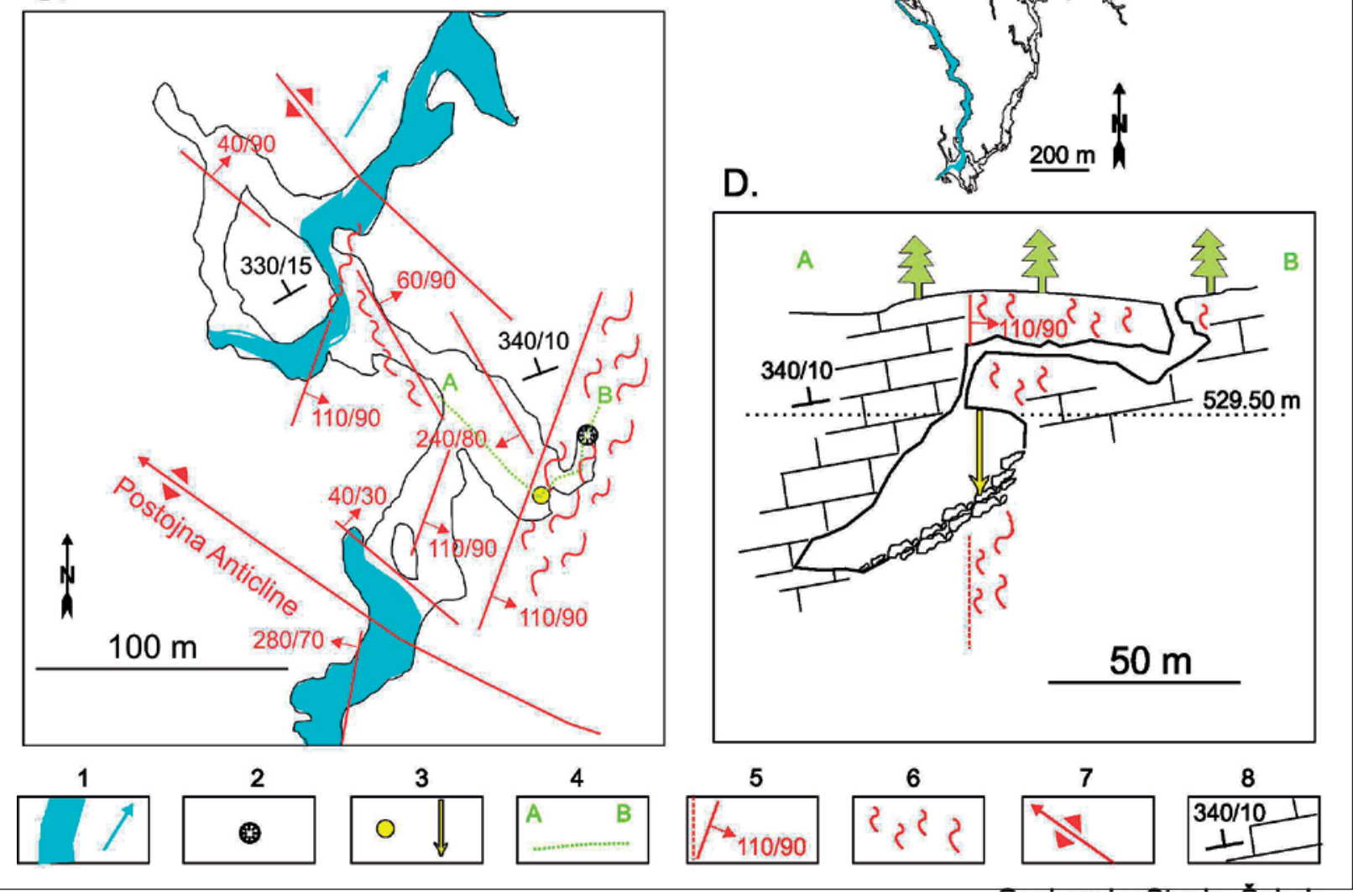

Fig. 3: Geology of Magdalena Jama and position of vertical static pendulum. A-Position of the studied area in Slovenia, B-Postojna Cave System ground-plan, C-geology of Magdalena Jama, D-cross-section AB. 1-underground Pivka River flow, 2-entrance to Magdalena Jama, 3-position of vertical pendulum, 4-cross-section AB, 5-strike and dip direction of fault (dashed-supposed fault), 6-fissured zone, 7-anticline axis, 8-strike and dip direction of limestone bedding.

Adria margin include the Dinaric thrust system, the South-Alpine thrust system and Dinaric faults (Vrabec \& Fodor 2006). Dinaric faults cut and displace both Dinaric and South-Alpine fold-and-thrust structures.
Most of them are characterized by moderate historic and recent seismicity.

The studied area is part of the Javorniki-Snežnik thrust unit, which has been thrusted over the Eocene 
flysch. The Hrušica thrust unit, representing upper Triassic dolomite, over-thrusts the Javorniki-Snežnik thrust unit. Over-thrusting took place after the deposition of the Eocene flysch. During the Miocene and Pliocene, the over-thrusting was accompanied by folding. The principal folding deformation in Postojna Cave System is the Postojna anticline (Fig. 3).

The Postojna Cave System is situated between two regionally important faults with NW-SE Dinaric orientation. These are the Idrija Fault to the north and the Predjama Fault to the south. The tectonic structure of the area between those two faults has typical characteristics of the intermediate zone between two dextral strike-slip faults. The cave passages of the Postojna Cave System follow the strike and dip of the bedding planes, especially those with interbedded slips. They are developed in both flanks of the Postojna anticline. They also follow Dinaric and
cross-Dinaric (NE-SW) oriented fault zones and mostly north-south oriented fissured zones (Šebela 1998).

Magdalena Jama is developed in Upper Cretaceous limestones in the north-eastern flank of the Postojna anticline (Šebela 1998). The entrance shaft is developed inside a subvertical-fissured zone with $110^{\circ}$ dip direction. The fissured zone is limited by the fault plane that is clearly visible on the south-eastern part of the cave wall. Within this fault the pendulum is installed. Further to the north-west of the cave the Dinaric-oriented (NW-SE) faults and fissures can be detected. About $100 \mathrm{~m}$ north from the Postojna anticline another anticline axis, of secondary importance, runs through the northern branch of the underground Pivka channel (Fig. 3) and further south in the cave system is cut by Postojna anticline. The general dip direction of Upper Cretaceous limestones is towards the north-west with a dip angle of $10-15^{\circ}$.

\section{FIRST RESULTS OF TILT MEASUREMENT IN MAGDALENA JAMA}

Because the pendulum in Magdalena Jama is far from the town, we have chosen solar panel(s) as a power source for the apparatus. We started the measurement in 2009 with only one solar cell with a maximum power output of $110 \mathrm{~W}$ in ideal conditions. Because the location of solar panel in the forest clearing was outside the direct solar radiation in winter, the back-up battery was damaged and no measurement was recorded during the whole winter. Reliable data were obtained only from 3 July 2010. Therefore, we moved solar panel to the highest tree in the surroundings in October 2010. Although the solar radiation at this place was as great as possible, the power output of 110W was not enough to supply two PCs with 10W power consumption each and the gaps in the measurement ranged from hours up to days during the winter 2010/2011 (Fig. 7).

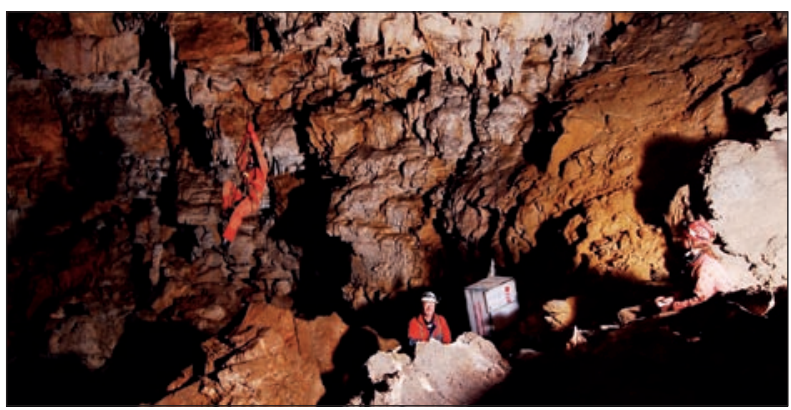

Fig. 4: The pendulum in Magdalena Jama, near Postojna, Slovenia in 2010 (Photo by Jan Kučera (C2010). View to the east on NE-SW oriented fault plane with pendulum.
We reconstructed the whole power system of the apparatus on 22 May 2011 by adding a new solar panel of

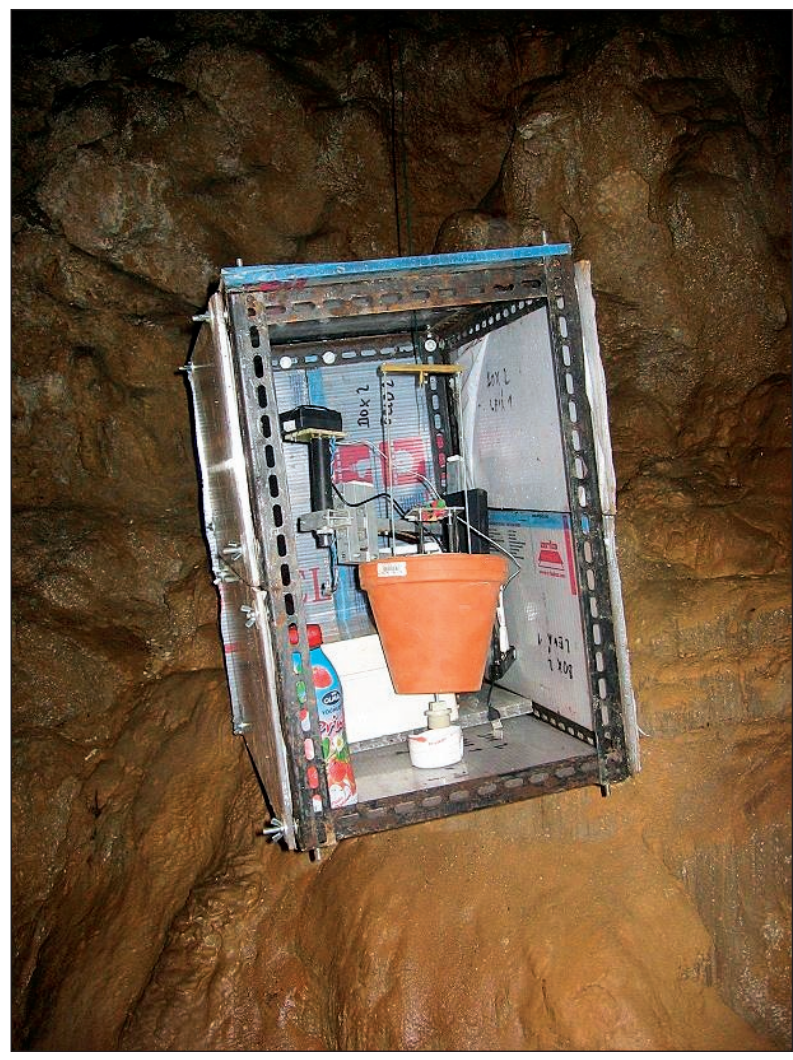

Fig. 5: Detail of pendulum in wind-protection box (Photo by Pavel Kalenda (C2009). 


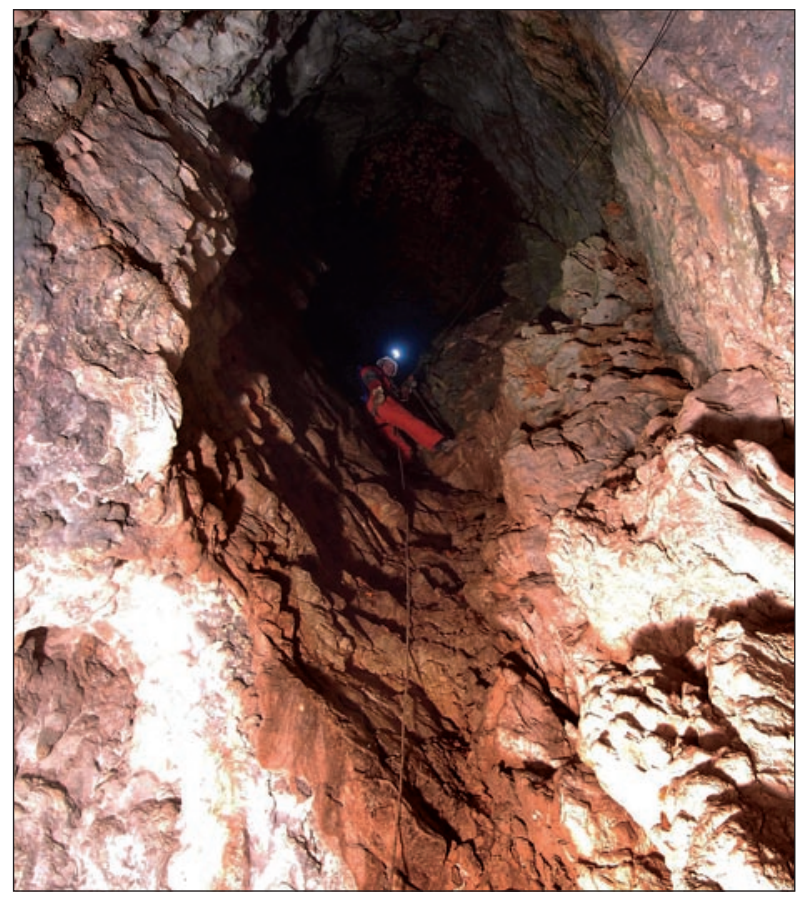

90W (thus the total output was 200W) and we changed the battery. There was no interruption of the measurement during the whole summer of 2011 despite poor weather conditions. The first periods when the power output was not enough for the power of whole system, started in October 2011, when solar radiation was less than 8 hours per day and the average output of solar panel was less than $20 \%$ of the declared maximal output. During the winter 2011/2012 there were two interruptions of the measurement longer than 4 days (4 December 2011 and 4 January 2012) due to snow cower and extreme drop of temperature. The average period of gaps in measurement was $6-16$ hours when the battery was not recharged enough during the short solar period.
Fig. 6: Upward view from the bottom of the entrance shaft of Magdalena Jama (Photo by Jan Kučera (02010).

The quality of measurement was not the same during the whole period of observation between 2010 and 2012 and it depended on the focus of the microscope. We estimated the quality of the measurement by the back-up pictures, which are taken each hour. We scaled the quality of measurement to from 0 to $1(0 ; 1)$. The quality " 1 " means that the contours of the letters of the raster are excellent. The quality " 0.5 " means that the contours are visible and the relative movement of the pictures can be evaluated easily. The error of evaluation of the position is some pixels. The quality " 0.3 " means that the contours are not sharp, but the movement can be evaluated, but without details. The error of evaluation of the position is less than ten pixels. The quality " 0.1 " means that the picture of the raster is on the edge of distinction and data are not adequate for next analysis (for example the period between January and May 2011).

Four parameters were measured by pendulum in Magdalena Jama. The tilt of the plumb line in the NS and EW directions, which were evaluated as an average of raw tilt in a 30-minute window and the "noise" parameters in NS and EW directions, which were evaluated as the variations of tilt in 30-minute window (Fig. 8).

Because the measurement of the tilt is absolute and we can compare the positions at any time with the time zero (Neumann \& Kalenda 2010), we could extend the movement/tilt during the whole period of the measurement independently on the measurement gaps. We started the new measurement three times at the $(0.0)$ position - on 3 July 2010, on 22 October 2010 after the movement

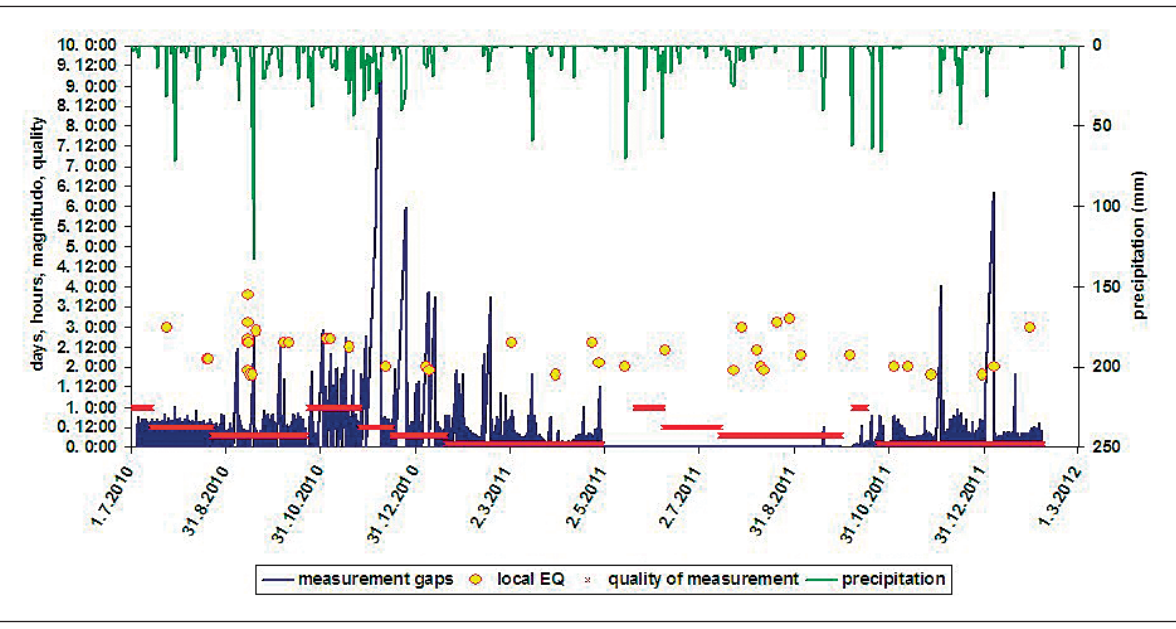

Fig. 7: Measurement gaps, precipitation, quality of data and local seismic events in Magdalena Jama. 


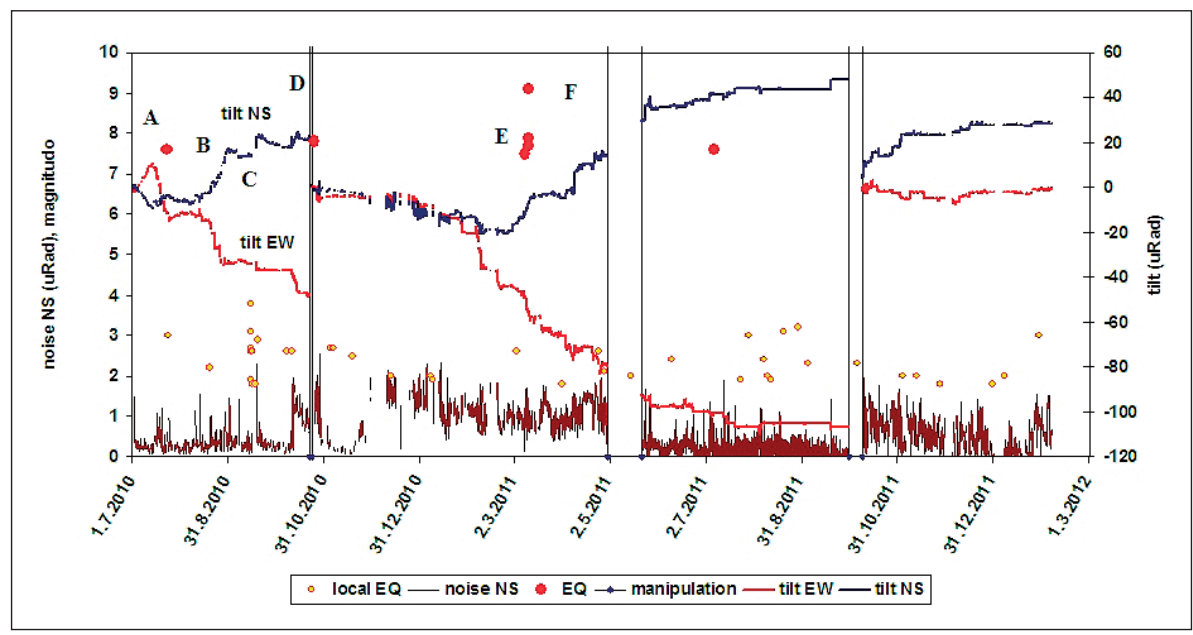

Fig. 8: Tilt of pendulum in Magdalena Jama, noise of tilt, local and worldwide earthquakes.

of the solar panel to the new position and on 9 October 2011 (Fig. 8). All parts of the measurement can be linked with previous part(s).

We can assess the development of the pendulum tilt in Magdalena Jama from two points of view - from the point of view of tilt itself in two directions NS and
EW and from the point of view of the tilt noise, which is defined as a variation of the tilt around average position in 30-minutes long time window (Neumann \& Kalenda 2010) and represents the speed of deformation. Our aim in both cases is to evaluate or estimate the development of the stress in the pendulum's surrounding massif.

\section{THE PERIODS OF ANOMALOUS DEVELOPMENT OF TILT AND NOISE}

We can estimate the relative stress in the SE direction (part of stress tensor) by measuring the deformation of the SE wall of the chamber (Fig. 3C) according to Hook's law

$$
\sigma_{i j}=\sum_{i j} c_{i j k l} \cdot \varepsilon_{k l}
$$

Because the blocks of Earth's crust can be regarded as beams with one fixed end in the mantle and one free end on the Earth's surface (Fig. 1), such blocks will be inclined to the north when the force $\boldsymbol{F}$ increases and its direction is from south to the north. On the other hand, if the force $\boldsymbol{F}$ decreases and its direction is oriented in a northern direction, the blocks will incline to the south according to Hook's law.

In the real environment of the Earth's crust, the ideal beams with one fixed end are not present, and each block of crust reacts individually to increasing stress by individual deformation, rotation and movement, which are defined by the local geometry of the block's contact with other blocks, by stress transfer between blocks and the physical parameters of rock mass and faults between blocks. Such results in the apparently chaotic and opposite movements of blocks with various directions and amplitudes can be detected (Stemberk et al. 2003, Briestenský et al. 2007, Briestenský \& Stemberk 2007, Briestenský et al. 2011). In the first step we can compare data with the local and worldwide seismicity (ANSS 2010) to find the eventual connection between the strongest seismic events and deformation of rock mass, if there are any.

We can estimate the relative value of the main component of the stress tensor according to seismic or "deformation noise" in the area of the pendulum. If the Coulomb criterion

$$
C F S=\tau_{\text {slip }}+f \sigma_{\mathrm{n}}
$$

is fulfilled in any direction, then non-elastic deformations will occur and the seismic or "deformation noise" will increase. The shear stress $\tau_{\text {slip }}$ is evaluated in the slip direction, $\sigma_{n}$ is the normal stress in extension and $f$ is the friction coefficient.

In the whole period between 3 July 2010 and 7 February 2012 there were 6 significant changes or steps in the tilt in both directions NS and EW (Fig. 8):

$$
\begin{aligned}
& \text { A - around } 19 \text { July } 2010 \\
& \text { B - around } 23 \text { August } 2010 \\
& \text { C - around } 15 \text { September } 2010
\end{aligned}
$$


D - around 14 October 2010

E - between 5 February 2011 and 14 March 2011

F - around 9 April 2011.

The first anomalous tilt (A) around 19 July 2010 was accompanied by higher deformation noise (tilt variations). A small earthquake $(M=2.8)$ near Dravograd in the NE part of Slovenia was observed at the same time (24 July 2010) exactly one day after three earthquakes in Mindanao, Philippines, $M=7.4,7.4$ and 7.3. This development of tilt - mostly in the western direction - and higher noise are similar to other anomalous tilt, which preceded the other large earthquakes from this region (Indonesia) (Kalenda \& Neumann 2010). Therefore, we suppose that this event (A) has the same origin - changes of the tectonic stress on the global scale.

The second anomalous tilt (B) around 23 August 2010 was not in the direction to the west like the previous one, but to the north-west, which can be interpreted as the beginning of the relaxation phase in NS direction and increasing stress to the west. Such interpretation can be underlined by no increase noise. On the other hand another small local earthquake occurred on 20 August 2010 in NE Slovenia and a medium $(M=5.6)$ earthquake was observed on 22 August 2010 in the Ionian Sea. Both tilt events on 19 July and 23 August 2010 were accompanied by vertical movement, which was controlled and documented by focusing of the microscope. The figure of micro-raster was moved out of focus and the quality of measurement decreased after both first and second events (Fig. 7).

The anomalous tilt (C) in the NNW direction was observed around 19 September 2010 after a small seismic swarm southerly from Postojna on 15 September 2010. This tilt is probably connected with strong rain between 9 and 19 September 2010 (Fig. 7). No anomalous noise preceded such movement of rock mass, only the high precipitation.

The anomalous tilt to the WNW around 14 October 2010 (D) was accompanied by higher deformation noise (Fig. 7), which is a sign of higher stress. It was similar situation to that in case (A) and the event finished by a large earthquake in Kep. Mentawai region, Indonesia on
25 October $2010(M=7.7)$. Unfortunately, the pendulum was not in operation between 22 and 24 October 2010, and the tilt directly before the mainshock was not recorded. On the other hand, the pendulum recorded the sudden tilt deformations (in comparison with previous state) on 29 October 2010, i.e. 4 days after the mainshock exactly at the same time as other pendulums and seismometers in Central Europe (Kalenda et al. 2011a).

We can compare the observation from Magdalena Jama with other pendulums in Central Europe. For example, we show the development of the N-S tilt of pendulum in Ida gallery (Figs. 2 and 9) in eastern Bohemia near Malé Svatoňovice (Czech Republic), which is close to the principal NW-SE Hronov-Pořičí Fault, between 1 January 2011 and the Tohoku earthquake on 11 March 2011 (M=9) (event E).

The most important development of the tilt started around 8 February 2011, when the speed of tilt increased to the west and, higher than average noise, was observed (Figs. 8 and 9). This development was not connected with precipitation, because temperatures were below zero. No small local earthquakes were observed at that time. The tilt development completely changed its direction from WSW to NW around 3 March 2011. At the same time a small earthquake $(M=2.6)$ was observed near Cerkno NW of Postojna. The change of tilt development was not of local origin. The tilt of the pendulum in Magdalena Jama according to the "Tohoku anomaly" started on 8 February 2011, i.e. 31 days before the mainshock, and finished on 15 March 2011. After the Tohoku earthquake, the deformation wave was observed with its maximum on 22 March 2011 (Kalenda et al. 2011a).

According to our opinion, the tilt event (F) on 9 April 2011 can be described as "aftershock" sequence of the Tohoku earthquake, when another portion of deformation was released.

The Kermadec earthquake on 6 July 2011 ( $M=7.7)$ was accompanied by only small seismic micro-anomalies in the Central Europe, but the deformation wave was detected on 13 July 2011, i.e. 7 days after the main shock (Fig. 8).

\section{DISCUSSION}

Indirect stress measurement by vertical static pendulum shows that the global stress field (or regional stress field) exists and can be measured simultaneously at many distant places. The global stress field can be distinguished from local processes like floods, air pressure variations and precipitation. This global stress field manages the deformation and destruction of the rock mass.

Although modern science does not generally accept methods of predicting earthquakes deterministically, i.e. to assess the place, time window and magnitude of fu- 
ture earthquakes, we suppose that one of the best methods for earthquake prediction is to measure the stress in rocks continuously using direct or indirect methods (Crampin \& Gao 2009, Shi et al. 2009).

We recognize that the anomalous tilt is visible before large earthquakes (Kalenda et al. 2009, Neumann \& Kalenda 2010, Kalenda \& Neumann 2010).

The greatest changes in stress orientation and in stress state were observed before the biggest earthquakes on the Eurasian lithosphere plate. In our case strong earthquakes - Philippines EQs on July 2010, Mentawai EQ on October 2010 and especially the catastrophic Tohoku earthquake in 2011 and its fore- and aftershocks were accompanied and preceded by changes of stress field, which were detectable in Central Europe and Slovenia by tilt measurement by vertical static pendulums.

Regarding the studies performed with the Marussi tiltmeters (Grillo et al. 2011) karst caves deform contin- uously and are particularly sensitive to deformations induced by hydraulic loading (meteorological conditions). Tectonic tilting reflects the actual tectonic situation that shows the convergence of the Adriatic and Euro-Asiatic plates.

The main changes of the tilt in our case started around 1 March 2011 or slightly before (Fig. 8). The statement that the effects observed by pendulum in Magdalena Jama are caused mostly by air temperature changes, air pressure changes and by precipitation are not the case in Magdalena Jama, because in the whole February 2011 and the beginning of March 2011 there were no precipitation or dramatic changes of air pressure. Even the temperature variations in the depth of $30-200 \mathrm{~m}$ below the surface are negligible. On the other hand, such changes of the tilt were observed on pendulum in Ida mine $200 \mathrm{~m}$ below the surface (Fig. 9) and also on some other sites.

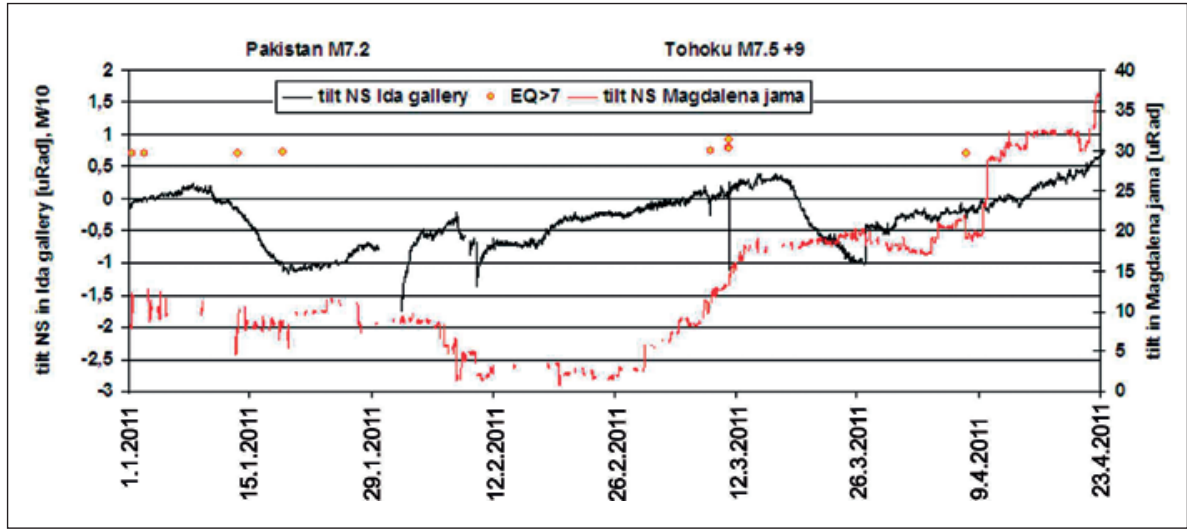

Fig. 9: Comparison of the developments of tilt in Magdalena Jama (Slovenia) with Ida gallery (Czech Republic. Circles mark the worldwide earthquakes of $M>7$.

\section{CONCLUSION}

Vertical static pendulums are used for indirect measurement of stress in the Earth's upper crust. In Magdalena Jama (Slovenia) a static vertical pendulum has been in operation since July 2010.

Tilt measurements by pendulums show that most of deformation anomalies are not of local origin, but they show the global scale of the stress field. Six anomalous periods of tilt and noise were recognized in Magdalena Jama during nearly two years long measurement. Five of them were connected with the largest earthquakes on our lithospheric plate and one anomalous tilt was most probably connected with high precipitation and extremely high floods in the area. We can express the hypothesis about relationship between local seismicity and anomalous tilt, and on the other hand high precipitation and low atmospheric pressure.

All anomalous periods were accompanied by low and moderate local seismic activity in Greece and Slovenia, which shows that local seismicity, can be connected with stress variations on a global scale, like the deformation of rock mass in Magdalena Jama.

The anomalous periods of the pendulum in Magdalena Jama are comparable with anomalous periods detected on other pendulums in Central Europe. It was shown that the tilt anomalies began at different times in different places depending on the local conditions, but they could be compared with each other, and a common tectonic frame can be detected. These anomalies precede the strongest earthquakes. 
The vertical static pendulum in Magdalena Jama (Slovenia) detected a change of general trend of tilt from E towards W (2010 - March 2011) to the direction towards NW (since March 2011), meaning uplifting of the SE blocks. The whole tilt during years 2010 - 2012 was in the order of $200 \mu \mathrm{Rad}$, which means that $26 \mathrm{~m}$ long pendulum moved for almost $6 \mathrm{~mm}$.

The measurements also show the tilt of $10 \mu \mathrm{Rad}$ towards NNW during extremely high floods in the area on 19 September 2010.
We could see an increase of noise before strong worldwide earthquakes (23 July 2010, and 25 October 2010). The Tohoku earthquake (11 March 2011) was specific by long periods of increasing stress (February 2011) and decreasing of stress days before the mainshock. The main tilt changes detected by the pendulum started on 2 February 2011 in an EW direction and on 1 March 2011 in a NS direction. The deformation and noise ended in May 2011 (Fig. 8).

\section{ACKNOWLEDGEMENTS}

The study was part of the Slovenia-Czech Republic bilateral project Micro-tectonic deformations in karst caves, exstensometers TM 71 and pendulum monitoring (BICZ/10-11-012). The research is included in EU FP7 INFRA project EPOS and EU FP7 IRSES project BlackSeaHazNet. We are thankful to Dr Matija Perne (Department of Geosciences, University of Arkansas, USA) and Stanislav Glažar (Postojnska jama d.d.) for their help during pendulum installation. Thanks to O. Kalenda and J. Kučera for their significant work during pendulum sta- tion maintenance. Franjo Drole (ZRC SAZU) succeeded in acquiring permission of private forest owners for solar cell installation. Thanks to Sklad kmetijskih zemljišč in gozdov of the Republic of Slovenia and Zavod za gozdove Slovenije OE Postojna for important information regarding the solar cell installation in forest. Many thanks go to Dr Elizabeth Covington for English review of the first manuscript and to Dr Trevor Shaw for revision of the final manuscript.

\section{REFERENCES}

ANSS Composite Catalogue, 2010: [Online] Available from: http://quake.geo.berkeley.edu/anss/catalogsearch.html [Accessed 2nd September 2011].

Biagi, P.F., Caloi, P., Migani, M. \& M.C. Spadea, 1976: Tilt variations and seismicity that preceded the strong Friuli earthquake of May 6 ${ }^{\text {th }}$, 1976.- Annali di Geofísica., 29, 137.

Braitenberg, C. 1999: The Friuli (NE-Italy) tilt/strain gauges and short term observations.- Annali di Geofísica, 42, 4, 637-664.

Braitenberg, C., Romeo, G., Taccetti, Q. \& I. Nagy, 2006: The very-broad-band long-base tiltmeters of Grotta Gigante (Trieste, Italy): Secular term tilting and the great Sumatra-Andaman islands earthquake of December 26, 2004.- Journal of Geodynamics, 41, 164-174.

Briestenský, M. \& J. Stemberk, 2007: Recent displacements registered in selected caves of Dobrá Voda karst area in Slovakia.- Acta Geodyn. Geomater., 4, $1,31-38$.
Briestenský, M., Stemberk, J. \& L. Petro, 2007: Displacements registered around March 13, 2006 Vrbové earthquake $\mathrm{M}=3.2$ (Western Carpathians).- Geologica Carpathica, 58, 5, 487-493.

Briestenský, M., Stemberk, J., Michalík, J., Bella, P. \& M. Rowberry, 2011: The use of a karstic cave system in a study of active tectonics: fault movements recorded at Driny Cave, Malé Karpaty Mts (Slovakia).Journal of Cave and Karst Studies, 73, 2, 114-123.

Crampin, S. \& Y. Gao, 2009: GEMS: A global earthquake monitoring system that could stress-forecast all damaging earthquakes worldwide. International Symposium on Earthquake Seismology and Earthquake Predictability, July 5-9, 2009, Beijing, China.[Online] Available from: http://www.124.17.4.5/ English/Symposium/index.htm [Accessed $4^{\text {th }}$ May 2012]. 
Gosar, A., Šebela, S., Košták, B. \& J. Stemberk, 2009: Surface versus underground measurements of active tectonic displacements detected with TM 71 extensometers in Western Slovenia.- Acta Carsologica, $38,2-3,213-226$.

Gosar, A., Šebela, S., Košták, B. \& J. Stemberk, 2011: On the state of the TM 71 extensometer monitoring in Slovenia: seven years of micro-tectonic displacement measurements.- Acta Geodyn Geomater., 8, 4, 389-402.

Grillo, B., Braitenberg, C., Devoti, R. \& I. Nagy, 2011: The study of karstic aquifers by geodetic measurements in Bus de la Genziana station - Cansiglio plateau (Northeastern Italy).- Acta Carsologica, 40, $1,161-173$.

Kalenda, P., Neumann, L. \& I. Wandrol, 2009: Indirect stress measurement by static vertical pendulum.Proceedings of 47th Int. Sci. Conf. Experimentální analýza napětí 2009, TU Liberec, 120-128.

Kalenda, P. \& L. Neumann, 2010: Static vertical pendulum - observations of anomalous tilt before earthquakes (case study).- In: Xie, F. (ed.) Rock stress and earthquakes. Taylor \& Francis Group, pp. 795-803, London.

Kalenda, P., Holub, K., Rušajová, J. \& L. Neumann, 2011a: Tracing of travelling of stress-deformation waves after Honshu earthquake. XXV IUGG General Assembly, Earth on the Edge: Science for a Sustainable Planet, 28 June - 7 July 2011, Melbourne.- [Online] Available from: http://www.iugg2011.com/abstracts/pdf/abstracts/81106015_KALENDA06080. pdf [Accessed $4^{\text {th }}$ May 2012].

Kalenda, P., Košták, B., Stemberk, J., Neumann, L. \& S. Šebela, 2011b: Micro-tectonic movements in karst caves (Slovenia) as indicators of Earth's stress changes - earthquake precursor implications.- In: Pekevski, L. et al. (eds) Complex Research of Earthquake's forecasting possibilities, seismicity and climate change correlations, 2-5 May 2011, Ohrid, FYR of Macedonia, BlackSeaHazNet series, vol. 1, Seismological Observatory and Faculty of Natural Sciences and Mathematics, 159-173, Skopje.

Košták, B., Mrlina, J., Stemberk, J. \& B. Chán, 2011: Tectonic movements monitored in the Bohemian Massif.- Journal of Geodynamics, 52, 34-44.

Li, J.Z., Bai, Z. Q., Chen, W. S., Xia, Y. Q., Liu, Y. R. \& Z.Q. Ren, 2003: Strong earthquakes can be predicted: a multidisciplinary method for strong earthquake prediction.- Natural Hazards and Earth System Sciences, 3, 703-712.
Marble Project, 1996: Feature space transformation for line detection, The Marble Project, Interactive Vision, April 1996.- [Online] Available from: http:// www.dai.ed.ac.uk/CVonline/LOCAL_COPIES/ MARBLE/medium/contours/feature.htm [Accessed 15th October 2011].

Márton, E., Čosović, V., Drobne, K. \& A. Moro, 2003: Palaeomagnetic evidence for Tertiary counterclockwise rotation of Adria.- Tectonophysics, 377, 143-156.

Melchior, P.J., 1983: The Tides of the Planet Earth.- Pergamon Press, pp.458, Oxford.

Neumann, L., 2007: Static Pendulum with Contactless 2d Sensor Measurements Open the Question of Gravity Dynamic and Gravity Noise on the Earth Surface.- Physics Essays, 20, 4, 535-552.

Neumann, L. \& P. Kalenda, 2010: Static vertical pendulum - apparatus for in-situ relative stress measurement.- In: Xie, F. (ed.) Rock stress and earthquakes. Taylor \& Francis Group, pp. 255-261, London.

Shi, Y., Zhang, H., Liu, Ch., Cao, J. \& Y. Sun, 2009: How far are we from numerical earthquake prediction? International Symposium on Earthquake Seismology and Earthquake Predictability, July 5-9, 2009, Beijing, China.- [Online] Available from: http:// www.124.17.4.5/English/Symposium/index.htm [Accessed $4^{\text {th }}$ May 2012].

Skalský, L., 1963: Tilt Observation Before Rockburst.Studia geoph. et geod., 7, $396-403$.

Skalský, L. \& J. Pícha, 1965: Evaluation of Rockbursts Observed in 1958-1961 at Tidal Stations of Březové Hory (Př́bram).- Travaux Inst. Géophys. Acad. Tchécosl. Sci., 199, 97-165.

Staš, L. \& K. Souček, 2002: Horizontal Stress field of carboniferous massif in Eastern Czech part of the Upper Silesian Basin.- In: Narasimhan, S.L., \& T., Ramamurthy, (eds.), ISRM Regional Symposium, Advancing Rock Mechanics Frontiers to Meet the Challenges of $21^{\text {st }}$ Century, Proceedings, $24-27$ September 2002, New Delhi, Central Board of Irrigation and Power, 1-10, New Delhi.

Stemberk, J., Košták, B. \& V. Vilímek, 2003: 3-D monitoring of active tectonic structures.- Journal of Geodynamics, 36, 103-112.

Šebela, S., 1998: Tectonic structure of Postojnska jama cave system.- ZRC publishing, 18, pp. 112, Ljubljana.

Šebela, S., Vaupotič, J., Košták, B. \& J. Stemberk, 2010: Direct measurement of present-day tectonic movement and associated radon flux in Postojna Cave, Slovenia.- Journal of Cave and Karst Studies, 72, 1, 21-34. 
Vrabec, M. \& L. Fodor, 2006: Late Cenozoic tectonics of Slovenia: Structural styles at the North-Eastern corner of the Adriatic microplate.- In: Pinter, N. et al (eds.) The Adria Microplate: GPS Geodesy, Tectonics and Hazards. Proceedings of the NATO Advanced Research Workshop on The Adria Microplate, NATO Sciences Series, VI, Earth and Environment Sciences, 61, pp. 151-168, Springer. 